Luxembourg Income Study Working Paper No. 272

TRENDS OF POVERTY AND INCOME INEQUALITY IN CROSS-NATIONAL

COMPARISON

Veli-Matti Ritakallio

August 2001 


\section{Trends of Poverty and Income Inequality in Cross-National Comparison}

by

Veli-Matti Ritakallio 


\section{Abstract: Trends of Poverty and Income Inequality in Cross-National Comparison}

Comparative research of poverty, income inequality and the effectiveness of income transfer systems has flourished during the last two decades, largely owing to the contribution of the Luxembourg Income Study -project. So far, however, the majority of comparative analyses have been based on a single year. For this paper we analysed cross-national patterns of poverty and income inequality with a special emphasis on their stability. We studied trends of poverty and income inequality between 1980 and 1995 in nine countries representing three different ideal types of social policy.

The differences in poverty across the countries studied corresponded with the respective models of social policy more clearly in the mid-1990s than they did 15 years earlier. Generally speaking, the poverty rate is slightly under $5 \%$ in the Nordic countries, around $7.5 \%$ in Central Europe, $10 \%$ in Canada, $12.5 \%$ in the UK, and as high as $17.5 \%$ in the USA.

All the countries included in the analysis share the trend that the primary distribution - based on the market income - has become less equal than before. In each country, the proportion of population being able to gain subsistence from the market alone has decreased continuously. This trend is significantly more remarkable than the change in actual poverty, which means that the absolute poverty alleviating impact of the income redistribution systems became stronger in these countries during the period 1980-1995.

The analysis of income inequality produced a basically similar picture of the differences across the countries and the models of social policy as the analysis of poverty did. In comparison to poverty, however, the change is generally speaking less extensive. The Nordic countries, in particular, have been capable of responding to the rise of the market income differences so that the income inequality for disposable incomes has practically not increased at all. Canada shows a parallel trend. The USA and, in particular, the UK represent the opposite development.

We also analysed trends of poverty in various population groups. It was found that by 1995 poverty had turned into a risk of young adults in all the countries studied. The poverty rate increased for the age group 18-30 years in all countries, while an opposite trend was observed among the elderly, in particular those aged over 65. Poverty rate among the elderly is nowadays below the average population-level rate in all the countries studied.

Keywords: Trends of poverty; inequality; income redistribution; welfare outcomes; comparative welfare research 


\section{Introduction}

The history of international comparative research on poverty and income inequality is relatively short, owing simply to the lack of commensurate empirical material. The pioneering work, Malcom Sawyer's (1976) comparison of income distribution in the OECD countries, was published merely twenty-five years ago. The Luxembourg Income Study (LIS) -project, is the most significant advancement in this field. Within the LIS, an income distribution database covering over 20 countries has been compiled to be used in comparative research. This database contains national data about annual incomes (including earnings, capital and self-employment incomes, as well as received and paid income transfers) for 2,000-57,000 households per country. In addition, certain structural characteristics are recorded for each household, e.g. type of household, place of residence, number of wage earners, and the age, education, occupation and social status of the "principal" of the household. For most countries in the database, cross-sectional statistics on income distribution are available for several points of time (e.g. the years 1969, 1974, 1979, 1986, 1991 and 1994 for the USA). In practice, the LIS database provides material for reliable and flexible comparative research of issues such as income differences, income distribution, income profile, poverty, and the effectiveness of social political arrangements in reducing income inequality. Until ten years ago, researchers comparing welfare states had to abide by aggregate analyses based on, for instance, the GNP share of social expenditure. According to Deborah Mitchell (1991, 163-166), a larger welfare state is often a better welfare state too, as the extent of total social expenditure correlates negatively with income inequality. In principle, however, it is possible to allocate social expenditure so that it does not reduce poverty or income inequality. Consequently, the analyses of welfare outcomes and micro-level data constitute a more reliable starting point for the comparison of welfare states.

A large number of international studies based on the LIS material have been published in recent years. Among the most significant studies are the comparison of the income transfer systems in ten countries by Mitchell (1991), the comparison between income and poverty differences in the 
OECD countries by Atkinson, Rainwater and Smeeding (1995), and the international child poverty comparison by Bradbury and Jäntti (2000).

The present article reports on a comparative study of poverty and income inequality, as well as the effectiveness of income transfer systems in nine countries representing three different welfare state models. The focus of this study is on the stability of differences between the countries across the four cross-sectional comparisons over a period of 15 years (in 1980, 1985, 1990 and 1995) How stable is the order between the countries and the models of social policy? Most previous studies have involved comparisons at a single point of time, and the results of these studies have been fairly harmonious. Among the OECD countries, the highest poverty rate, the largest income inequality, and the least effective income transfer system are found in the United States of America. Other English-speaking countries follow the US example, though at a good distance. The Nordic countries, occasionally accompanied by the Netherlands, stand at the opposite end of the scale. As the Southern and Eastern European countries are excluded from most studies, the mid-range between the Anglo-Saxon world and the Nordic countries is occupied by the Central European countries. (Cf. Mitchell 1991; Atkinson et al. 1995.)

Comparisons based on one point of time and the emerging picture of cross-national differences can be criticised as being too limited. The results may, in principle, reflect differences in economic trends or structural changes of societies rather than disparities in the effectiveness of social policy. Countries differ from each other, for example, in the pace of transition from one-provider to two-provider family pattern. The analysis of more than one cross-sectional comparison over a longer period of time and the consideration of structural disparities will yield a more reliable and analytical picture of the stability of differences across the countries and the various models of social policy. This approach also allows us to investigate the extent to which the observed differences result from structural differences, economic trends, or institutional differences pertaining to social policy. 
Cross-national differences in poverty risks attached to various population groups are discussed in this article, in addition to differences at population level. What can be observed when the differences in the extent of poverty are constant and the focus is on the comparison of different population groups? The question is: Do different types of welfare states treat various population groups in an equal manner, or do the countries differ from each other also in this respect? And how has the population profiles of poverty chanced? It is possible that aggregate level figures show no change, while at the same time the detailed group level approach reveal major changes. According to the classic phase-of-life theory, the poverty risk varies across different episodes of life and types of family (Rowntree 1901). Under circumstances of underdeveloped social policy, poverty affects families with children and the elderly most severely. The latest research suggests that a generally low poverty rate is associated with relatively smaller differences between the various population groups who are at risk of poverty (see Kangas \& Palme 1998). Social political measures aiming at improving the status of families with children and the elderly have had the desired effect. It must, however, be borne in mind that in the past hundred years following Rowntree's study (1901) the typical course of life has altered. Today, young adulthood is no longer necessarily the prime phase of life in financial terms. Longer periods of study and the relatively high youth unemployment are new factors affecting the livelihood of young adults. On the other hand, the situation of families with children has improved along with the declining average number of children per family. In the present paper, cross-national differences and changes in the incidence of poverty in various population groups are investigated for the years 1980 and 1995. Do the national results support the assumption that poverty is no longer an issue affecting families with children and the elderly but rather an issue affecting the livelihood of young adults?

To summarise the study design, comparisons are made at three levels: between population groups, between points of time, and between countries or welfare state models. 


\section{Three models - nine countries}

The countries were selected for the comparative analysis to represent different social policy models or idealtypes. The theoretical foundation is the quadruple division of models of social policy presented by Walter Korpi and Joakim Palme (1993): the means testing model, the minimum protection model, the corporatist model, and the institutional model. (Cf. Titmuss 1958; Esping-Andersen 1990; Castles \& Mitchell 1990; Leibfried \& Ostner 1991; Korpi \& Palme 1998.)

Table 1. Characteristic features of various models of social policy

\begin{tabular}{|c|c|c|c|c|}
\hline \multirow[b]{2}{*}{ Dimension } & \multicolumn{4}{|c|}{ Model, representative country, and characteristic features } \\
\hline & $\begin{array}{c}\text { MEANS TEST- } \\
\text { ING } \\
\text { (UK, Canada, } \\
\text { USA) }\end{array}$ & $\begin{array}{l}\text { BASIC SECU- } \\
\text { RITY } \\
(-)\end{array}$ & $\begin{array}{l}\text { CORPORATIST } \\
\text { (Netherlands, } \\
\text { France, Germany) }\end{array}$ & $\begin{array}{c}\text { INSTITUTIO- } \\
\text { NAL } \\
\text { (Norway, Sweden, } \\
\text { Finland) }\end{array}$ \\
\hline $\begin{array}{r}\text { Coverage of social } \\
\text { policy }\end{array}$ & The poor & $\begin{array}{c}\text { The entire popula- } \\
\text { tion }\end{array}$ & $\begin{array}{l}\text { Linked to em- } \\
\text { ployment }\end{array}$ & $\begin{array}{l}\text { The entire popula- } \\
\text { tion }\end{array}$ \\
\hline $\begin{array}{r}\text { Level of basic } \\
\text { security }\end{array}$ & Low & Sufficient & Low & Sufficient \\
\hline Means testing & Key feature & Not essential & Not essential & Not essential \\
\hline $\begin{array}{r}\text { Earnings-related } \\
\text { benefits }\end{array}$ & $\begin{array}{c}\text { Based on private } \\
\text { insurances }\end{array}$ & $\begin{array}{l}\text { Based on private } \\
\text { insurances }\end{array}$ & $\begin{array}{c}\text { The employed are } \\
\text { covered }\end{array}$ & $\begin{array}{c}\text { The employed are } \\
\text { covered }\end{array}$ \\
\hline $\begin{array}{r}\text { The State's role in } \\
\text { social policy }\end{array}$ & Limited & Moderate & Moderate & Extensive \\
\hline $\begin{array}{r}\text { Universal public } \\
\text { services }\end{array}$ & None & Some & None & $\begin{array}{l}\text { Day care, educa- } \\
\text { tion, health serv- } \\
\text { ices, care of old } \\
\text { people etc. }\end{array}$ \\
\hline
\end{tabular}

In the spirit of liberalism, the means-testing model is characterised by the minimal role of the state, both for services and for income security. A key principle is that families and individuals are primarily responsible for their own livelihood. The State's liability is restricted to the assistance of those who are unable to satisfy their needs through other channels. As far as income security is con- 
cerned, the principle of own responsibility is reflected in the preference for private insurances. Typical features of the public social policy include last-resort support, means testing, and the relatively low level of benefits and services. Up to the early 1970s, the United Kingdom was widely considered to represent the minimum protection model. In the minimum protection model, universal (non means tested) social policy covers the entire population, regardless of income. However, public social policy is considered to be responsible for securing minimum subsistence only. Benefits exceeding the basic security are expected to be obtained from the market. Since the late 1970s, social benefits have been heavily cut in the UK, and according to many researchers (e.g. Bradshaw 1999), the country's social policy has diverged from the basic security model towards the means testing model. By investigating the trends in the UK in 1980-1995, it is possible to evaluate the social impact of the neoliberal social development policy. In this study, the UK, Canada and the United States represent the means testing model of social policy. The minimum protection model is not represented by any country, since the social policy in the UK has been altered as described above.

Corporatist social policy is typical of many Central European countries. In the Central European countries public social policy is largely based on cash income transfers (redistribution). The provision of services is mainly the concern of voluntary organisations, particularly the church. It is characteristic of the corporatist social policy to link social security directly to employment. Income security does not cover the population in its entirety, but only those gainfully employed. The earnings-related social security is based on the individual's work performance. Universal minimum subsistence based on citizenship is foreign to this model. In many studies, the corporatist model is considered to rely on the idea of men as family providers - male breadwinners (Sainsbury 1996). Owing to less female participation in working life, social security for families depends, in most cases, on the husband's or father's employment. At the same time, social policy encourages women to stay at home. For instance, childcare systems are not developed so as to make it easier for women to 
participate in the labour market (Forssén 2000). The Netherlands, France and Germany (until 1990: the Federal Republic of Germany) were selected as being representative of the corporatist model of social policy in this study.

The State has an extensive role in satisfying the needs of citizens in institutional social policy. In addition to a comprehensive statutory income security system, the State is responsible for a wide range of public services. The aim is to establish social integration by offering equal access to highquality public services at an affordable price. In principle, all population groups are entitled to use the same services. Characteristic features of the income security include reasonable level of benefits, the central role of the State, and the principle of universality, i.e. social benefits are available for all citizens. The determinants of the reasonable level of benefits are the minimum security, on one hand, and the earnings-related security, on the other hand. The minimum security guarantees a reasonable basic subsistence for all citizens, irrespective of their work career. The earnings-related security is meant to secure the standard of living achieved in the labour market. Institutional social policy is typically exercised in the Nordic countries, and for the purposes of this study, the model is represented by Norway, Sweden and Finland.

The countries included in this study differ, not only in the institutions of social policy, but also in a number of demographic features and in labour participation (see Appendix 1). In the USA, the UK, Canada and France, a large proportion of population consists of individuals living in families with many children (three or more), traditionally at a high risk of poverty. Apart from Sweden, Finland and the Netherlands, the proportional share of families with many children has been declining in all of the countries included in this analysis. Thus, the differences across the countries have narrowed during the study period in this respect. Single parent families are another type of household exposed to poverty. The proportion of people living in single parent families is clearly lower in the Central European Catholic countries than in the other countries studied. If any change has taken place, the trend is slowly rising. In the English-speaking and Nordic countries the proportion of 
people living in single parent families varied between five and eight percent in 1995 . In all countries studied, people lived most frequently in a two-parent family with children; with 40 percent of the population representing this type of household. In all of these countries, however, the population share of the nuclear family type is in decline. In comparison with other Western countries, living alone is more common in the Nordic countries. With the exception of Canada, living alone is becoming more popular in all of the countries studied. The proportion of childless couples and the elderly has also increased slowly in all countries. Canada has the youngest and Sweden has the oldest population. The proportion of young households, with members aged 18-30 years, has declined in all countries, partly due to the fall in the size of age groups. Another factor explaining this trend is the fact that nowadays young people move from their childhood homes at an older age than ear-

lier (cf. Schneider 1999). Traditionally, labour participation has been a factor that explains clearly and independently variations in poverty. In this respect, the countries studied here differ significantly from each other. The family type with two providers has become predominant in all countries; except in Central Europe, and even there the model is rapidly spreading. Remarkably, the trend in the UK is different: the household type "other" - including households in which not all adult members are gainfully employed - is on the rise. The institutional and structural differences between the countries and the models of social policy are reflected in the poverty rates and the poverty profiles (see Rainwater \& Smeeding 1998; Kangas \& Ritakallio 2000).

\section{Data and methods}

The list of data-sets is given in Appendix 2. Altogether, the material covers approximately 378,000 households in nine countries, i.e. a population of almost one million individuals. For Finland, the data for the years 1981, 1985 and 1990 are based on household budget surveys by Statistics Finland. For the purpose of comparative analysis, the concept of 'income' used in the Finnish household surveys has been modified to correspond to the LIS concept of income. 
In this study, poverty is defined using the relative income method: If a household's disposable income per consumption unit is less than one half of the median annual income, the individuals living in that particular household are considered poor. The used consumption unit scale was the traditional OECD (see discussion of the scales e.g. Buhmann, Rainwater, Schmaus \& Smeeding 1988). The poverty line is determined from the country-specific materials and separately for each crosssectional set of data. To analyse poverty, the poverty rate and profile are examined. The poverty rate (poverty risk) indicates the proportional share of the poor in the whole population. For the poverty structure (profile) in each country, the poverty rate is constant (100), and the focus is on the percentual share of the poor in each population category. This analysis is necessary in order to evaluate the combined effect of concurrent structural differences between countries and poverty risk differences between population groups on the overall picture of poverty.

The Gini index, ranging between zero and one hundred (or zero and one), is used as the measure of income inequality: The lower the Gini index, the more equal the income distribution is, and vice versa. The often used intepretation of Gini values is the following (see e.g. Gottschalk, Gustafsson \& Palmer 1997): If the Gini index for the disposable income receives a value below 20, the income inequality is "very small" in the country in question. Values between 20-24, 25-29, and 30-34 indicate "small", "moderate" and "large" income inequality, respectively. Values exceeding 35 are interpreted to signify "very large" income inequality.

In this paper, the basic unit is an individual. In calculations, an individual's income is equal to the total income of the household divided by the number of the OECD consumption units in the household. Household data are converted into individual data by multiplying household data by the number of the household members. In some earlier studies, households or families have served as study units, with the household's total income divided by the OECD consumption unit factor as their income (e.g. Mitchell 1991). In this case, the weight of individuals living in small households is greater in comparison to individuals living in large households. According to Gustafsson and 
Uusitalo (1990), the individual-based analysis reveals the relative status of different population groups in a fair manner. The differences are particularly prominent when the poverty profile is examined. In practice, a larger proportional share of poor households than of individuals living in poor households are single people. Correspondingly, the proportional share of large households of all poor households is smaller than the proportion of individuals living in large households of all poor individuals.

\section{Standard method and its limitations}

The effectiveness of income transfer systems in reducing poverty and income inequality is measured using the standard method. The absolute impact of an income transfer system is, by definition, the difference between the poverty rate (or the Gini index) based on factor incomes (total incomes before transfers) and the poverty rate (or the Gini index) based on disposable incomes (incomes after transfers). The analyses based on factor incomes give an estimate of poverty and income inequality in a hypothetical situation without any kind of equalising social policy. We must, however, be cautious in drawing any conclusions, because people would obviously behave differently under alternative circumstances; for instance, the ageing population would continue longer in the working life. In other words, it is probable that, in the hypothetical world with underdeveloped social policy, poverty and income inequality would not be quite as extensive as suggested by the figures based purely on factor incomes (see Saunders 1994).

It has to be emphasized, however, that the above method measures only the direct redistributive impact of income transfers, not the effectiveness of the welfare system as a whole. The standard method ignores the social political regulations which influence the primary distribution (see Korpi 1983, 188-190; Ringen 1987). The best known example of a welfare state with a mechanism tackling the primary distribution of market income is Australia before 1980. The Australian system, called the "wage-earners' welfare state", aimed at safeguarding families with children from poverty 
by setting the minimum wage level so as to guarantee an income sufficient for a household with two adults and two children even when only one of the parents is employed (Castles 1985). The impact of this will not be revealed, if the standard method is used. Consequently, the effectiveness of the systems implementing the redistribution policy in forms other than income taxation and cash benefits will be evaluated lower than it is in reality.

Another problem in international comparisons is that the results are not completely fair when welfare states based on either cash income transfers or service policies are compared. The Central European countries, in which the social policy is implemented mainly through cash benefits, are undeservedly favoured in comparison to the Nordic countries, where the majority of social policy is realised through subsidised public services. The role of public services is neglected in incomeoriented analyses, partly due to a lack of comparable material (cf. Saunders, Smeeding, Coder, Jenkins, Frizell, Hagenaars \& Wolfson 1992; Saunders 1994, 185-190). The problem becomes more pronounced when the effectiveness of systems in levelling out the poverty gap is analysed in monetary terms. Saunders and co-workers (1992) showed, in their comparison of seven countries, that the pattern of income distribution does not change much, if the calculatory advantage of the subsidised public services is taken into consideration, in addition to the disposable income. This so far is the only comparative analysis of the public services and income distribution which suggests that the comparative picture of relative poverty and income inequality would not change essentially, even if the value of public services were taken into consideration.

Finally, it must be pointed out that, in the interpretation of the results of international studies on poverty and income inequality, the structural disparities between the countries (see Appendix 1) have not usually been accounted for. It has been assumed that the observed differences result from differences in the effectiveness of the welfare systems. The truth is, however, that the countries differ greatly in aspects such as labour participation and types of households, as discussed above. For this reason, the pressures set on social policy vary from one country to another. Two studies pub- 
lished recently (Rainwater \& Smeeding 1998; Kangas \& Ritakallio 2000) focused on analysing the roles of income transfers and structural factors in explaining the observed differences. Comparing the poverty rates in France and in the Nordic countries, Kangas and Ritakallio (2000) showed that one third of the difference between the poverty rates (3.7 percent units) is explained by income transfers and two thirds by various structural differences. The most powerful explanatory factor was the variation in labour participation.

In this paper, the analysis of the systems' effectiveness is restricted to the direct impact of income transfers. The effects of structural differences are seen in the comparison of welfare outputs according to poverty rates. The problem is that the effects of structural differences underlying the observed variation in poverty are not analysed more thoroughly.

\section{Trends of poverty and income inequality}

Our analysis of poverty and income inequality yields a complex picture of the relationships between the countries under study. The finding that poverty rates and income inequality are lower in the Nordic countries and higher in the USA is in line with earlier knowledge. This general conclusion is followed by a number of observations highlighting differences between various models of social policy. Also, differences between countries and groups of countries in poverty and income inequality levels have actually varied throughout the period studied. The poverty and income inequality analyses do not for all parts produce a homogeneous picture of the said differences.

At all the four points of time, the USA had the highest poverty rate. The Nordic countries, accompanied in the early 1980s by the Netherlands (1981-90) and Germany (1980), showed the lowest poverty rates. In 1980, Finland had a clearly higher poverty rate than the other Nordic countries, or the Netherlands and Germany. Towards the end of the study period, the setting became clearer as far as the models of social policy are concerned: Sweden, Finland and Norway were found to be countries with a low poverty rate (under 5\%), while the Central European countries had higher pov- 
erty rates (about 7.5\%). In the 1990s, more than 10 percent of the population were poor in the countries representing the means testing model. The English-speaking countries differed clearly from each other: the poverty rate was about $10 \%$ in Canada, slightly over $12 \%$ in the UK, and as high as $17.5 \%$ in the USA. Throughout the period studied, the population share of the poor in the USA was about four-fold in comparison to the Nordic countries. Furthermore, the changes in poverty were heterogeneous in the countries studied. Although the trends were country-specific, the differences between the various models of social policy were obvious. The new way of exercising social policy in the UK resulted in the most significant individual change. The poverty rate rose from less than $7 \%$ in 1979 to more than $12 \%$ in 1995 . In Canada, the poverty rate tended to decrease, prevailing at around $10-11 \%$. In the USA, the poverty rate rose from $15 \%$ in 1979 to $17.5 \%$ in the later years of the period studied.
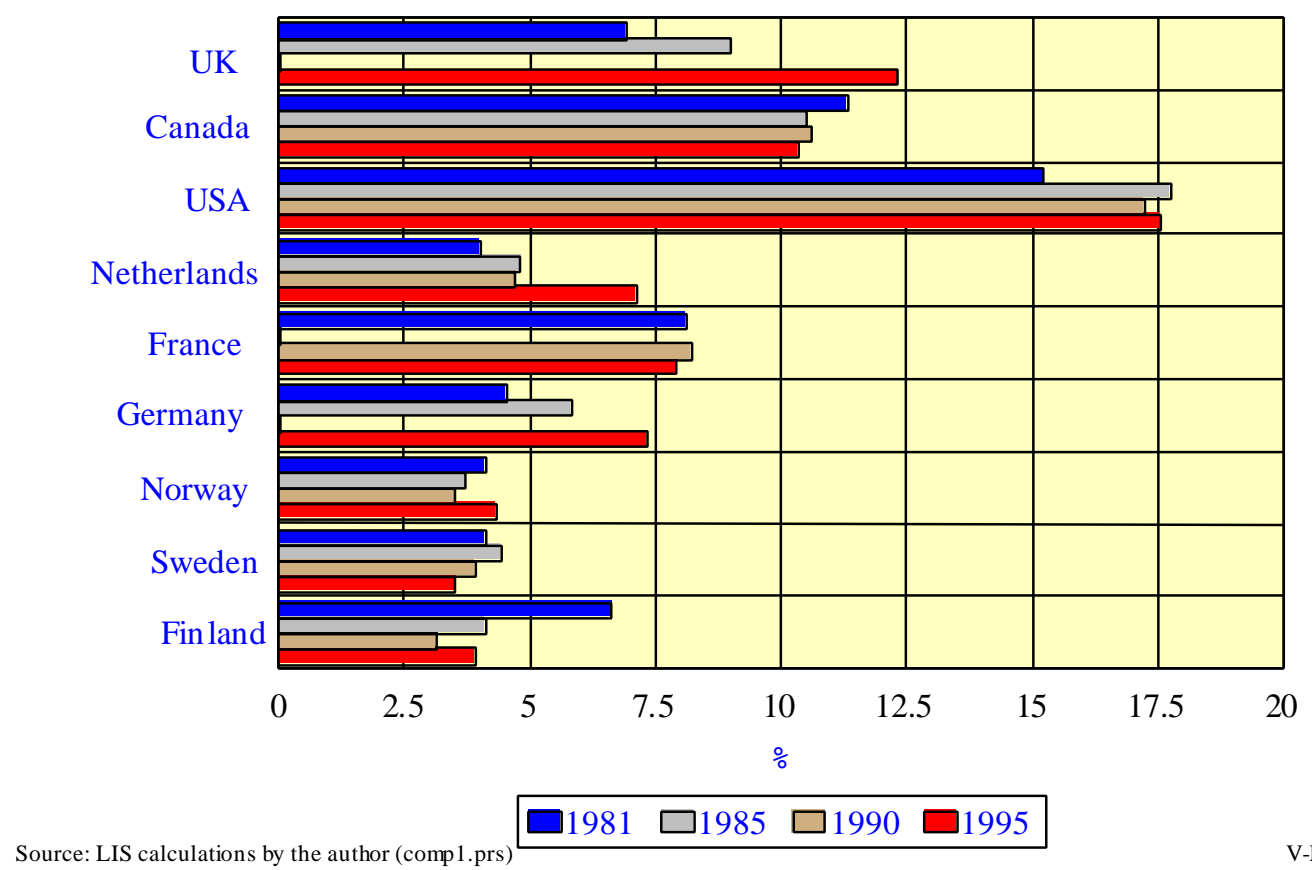

V-M Ritakalli

Diagram 1. Poverty rate in $1980-1995^{1}$

In the Central European countries, the poverty rate was typically around $7.5 \%$ in the mid1990s. Differences between the Netherlands, France and Germany were insignificant in 1995. The development paths in the Netherlands and Germany, however, deviate from those in France. Up to 
the 1980 s, especially the first half of the decade, the poverty rates in the Netherlands and Germany were similar to the Nordic countries. Of the Nordic countries, Finland showed a declining trend, and by the mid-1980s Finland reached the Nordic level (under 5\%) in this respect.

The analysis of income differences yields a parallel picture. In the Nordic countries, income inequality has been "small" or "very small" throughout the period studied. It is difficult to draw any clear conclusions about the development of income differences in the Nordic countries. However, it must be pointed out that the income differences were highest in the last year of study, i.e. 1995, for all countries. In the Central European countries, the income inequality was mostly "moderate". The direction of change is not clear, but the change in the extent of income inequality in France in comparison with the Netherlands and Germany is quite clear. For France, it is justified to speak about "large" income inequality, in contrast to "moderate" in the Netherlands and Germany.

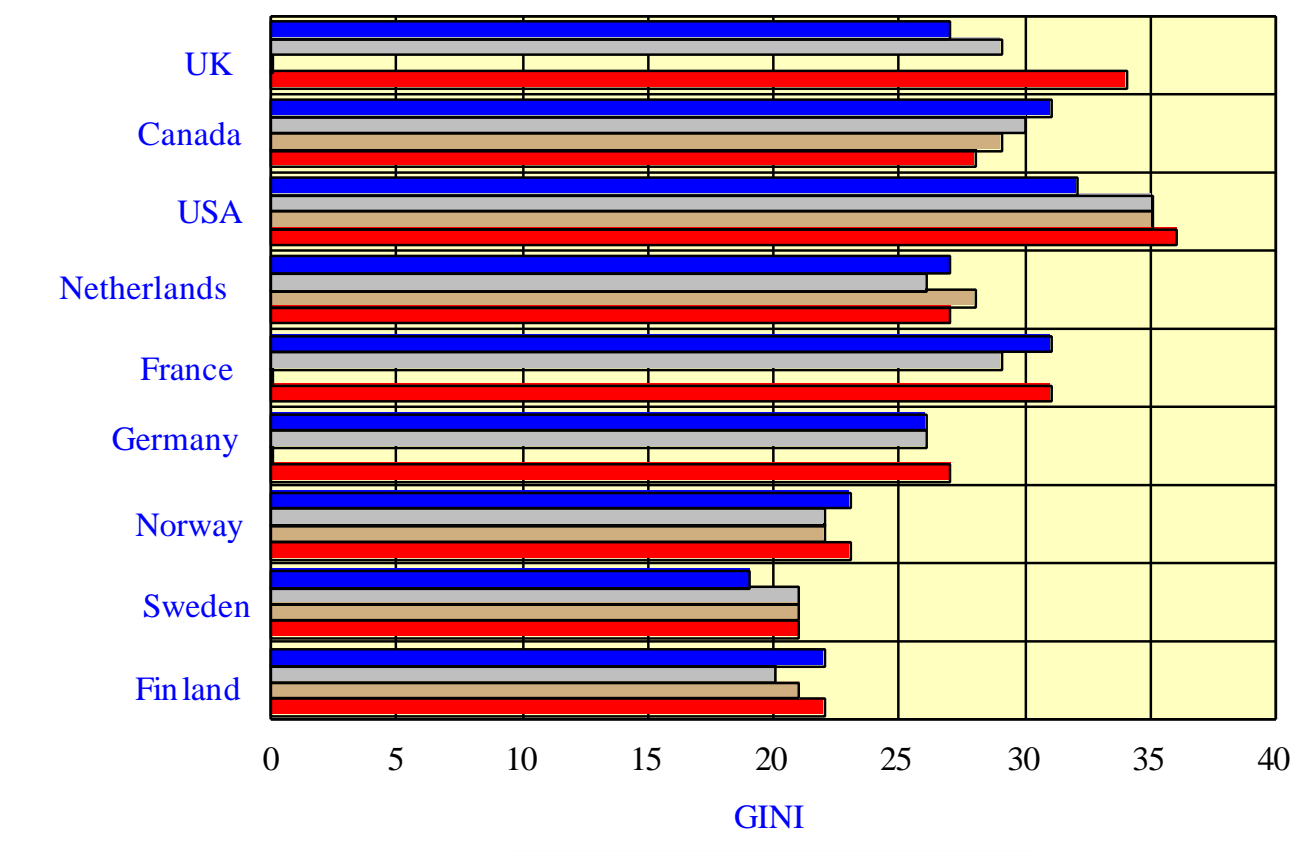

Source: LIS calculations by the author (comp2.prs

$\square 1980 \square 1985 \quad \square 1990 \quad \square 1995$

Diagram 2. Income inequality in 1980-1995 
The English-speaking countries are in a world of their own, and were subject to substantial changes during the study period. The UK was within the same range as the Central European countries up to the 1980 s, but in the 1990s the country showed the largest individual change in income inequality among the countries studied. The change of policy is reflected by a transition towards the US model of "large", or almost "very large" income differences. Also in the USA, income inequality has increased throughout the study period. Canada is an exception among the English-speaking countries: income differences narrowed in the period 1980-95. Today, the income inequality in Canada is closer to the Central European level than that of the other English-speaking countries.

\section{Trends of pre-transfer poverty and income inequality}

Diagrams 3 and 4 show the poverty rates and income inequality based on the factor incomes received from the market. The diagrams reflect the equality of the primary distribution in each country. How would the market income alone guarantee welfare in society? In this situation the income differences are much larger because, e.g., the ageing population receive practically no factor incomes. According to the standard method, the deviation between Diagrams 1 and 3 (income poverty), and respectively, Diagrams 2 and 4 (income inequality) indicates the country-specific differences and changes in the effectiveness of the income transfer systems in reducing poverty and inequality.

The following trend applies to all countries included in the analysis: The market income guarantees a sufficient level of income for fewer people than before. In the early 1980s, the share of this group was around 20-25 percent of the total population. On the basis of the market income, a total of 27 percent of the population in the Netherlands and Sweden and as much as 31 percent in France dropped below the poverty line at that time. Differences are a sum of many factors. Typically, the high poverty rate before income transfers results from a large proportional share of the elderly in the 
population, a high unemployment rate and the frequency of families with many children, as well as of student households. More generally speaking, this also involves the question of the nature of social policy, i.e. whether it encourages or compels citizens to work.

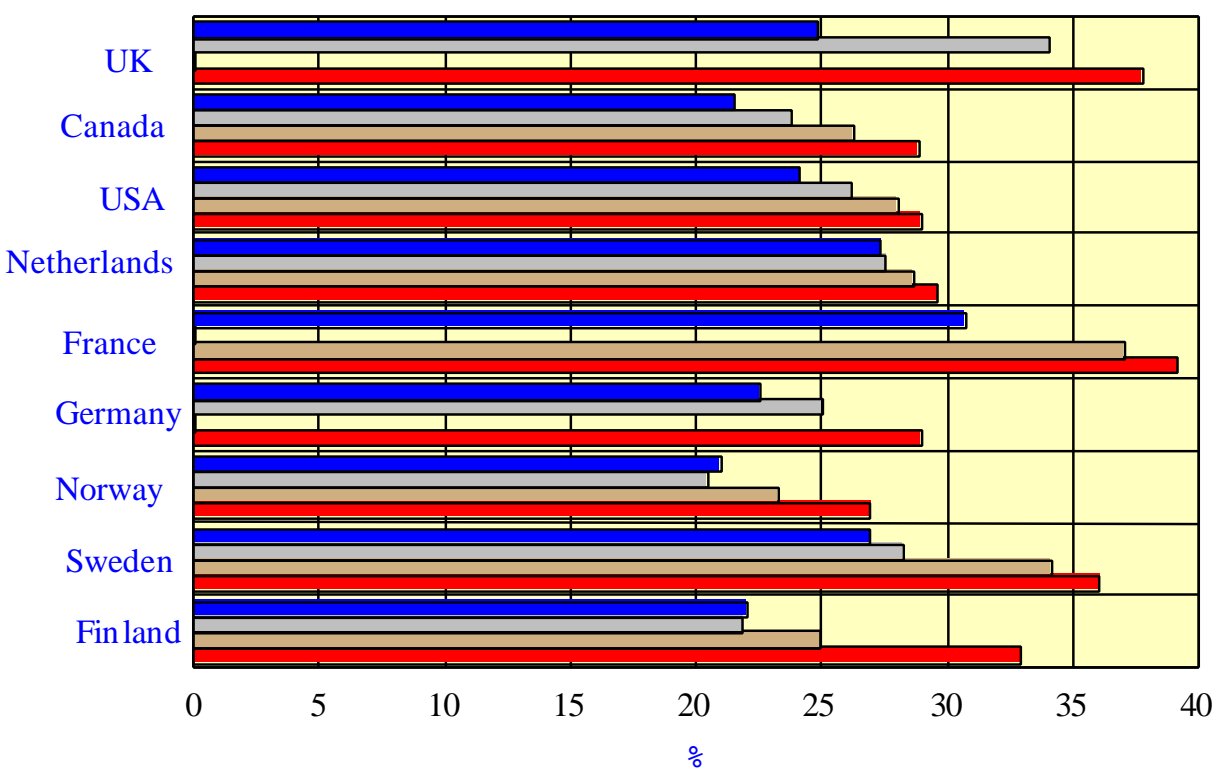

$1981 \square 1985 \square 1990 \square 1995$

Diagram 3. Poverty rate before income transfers, 1980-1995

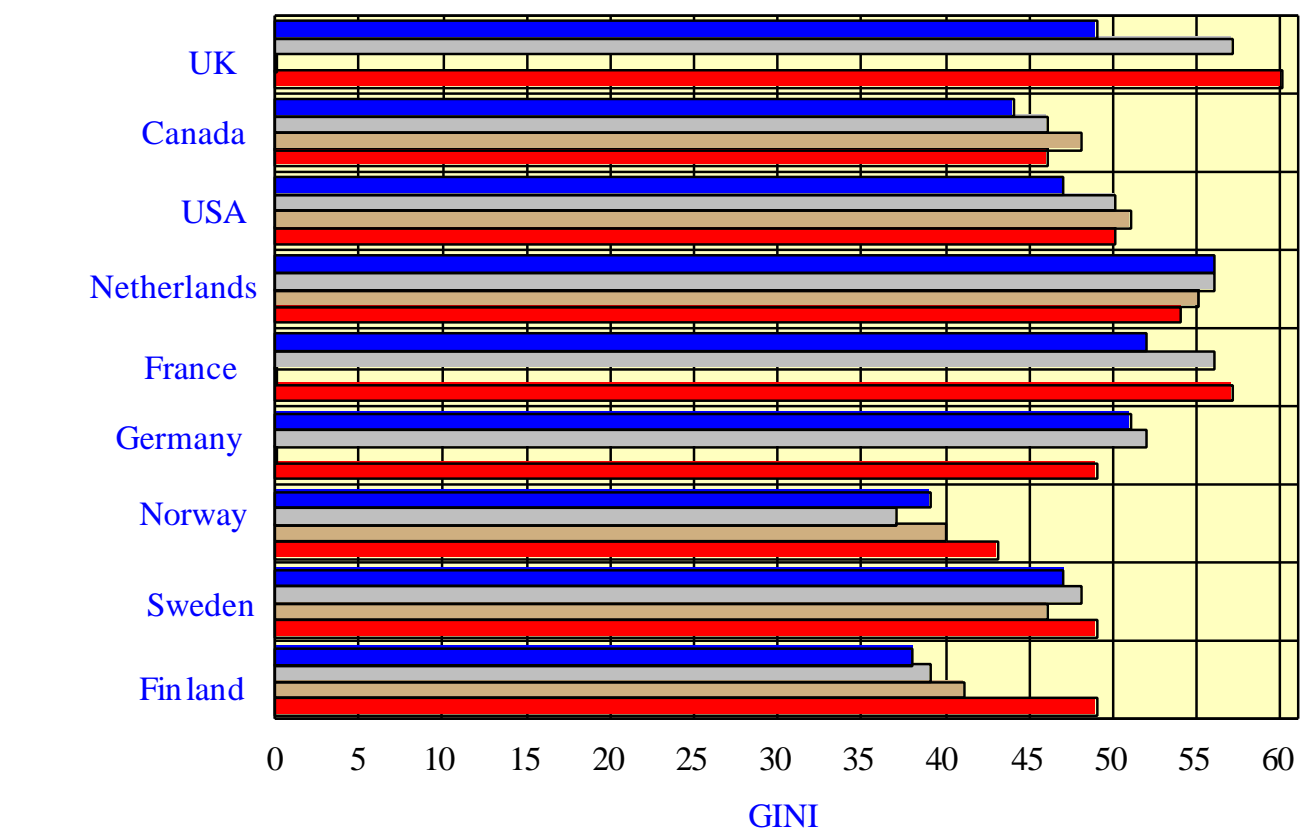

Source: LIS calculations by the author (comp2.prs) $\square 1980 \quad \square 1985 \quad \square 1990 \quad \square 1995$

Diagram 4. Income equality before income transfers, 1980-1995 
The population excluded from the market has increased especially in the UK and Finland. In these countries, the recent trends of unemployment and age profile have, extended the scope of responsibility of social policy. Comparison between Diagram 1 and 3 reveals that Finland managed its increasing burden better than the UK. In Finland the poverty rate remained low in spite of the pressure, while the same cannot be said about the UK. As far as the effects of the changed social policy in the UK are concerned, it must be pointed out that not all of the increase of "true" poverty (Diagram 1) is due to the cuts in social expenditure. The structural change of the labour market also caused a rise in poverty. The situation in Finland in the mid-1990s was by no means unique. As far as the scope of responsibility of social policy is concerned, the situation in France, the UK and Sweden was even worse than in Finland (see Diagram 3) although Finland at that time was in the deepest whirl of depression.

A similar trend can be observed for income inequality (Diagram 4), although it is not quite as clear-cut as for poverty rates. For Finland and Norway, in particular, the equality of the distribution of market income in the early 1980 s is striking. It corresponded to the distribution after income transfer in the United States in the mid-1990s (cf. Diagram 2). The UK and Finland have undergone the greatest changes in this respect. In both countries, the Gini index for the market income rose by more than 10 units in 15 years. The sharpest rise took place in the early 1980s in the UK, and a decade later in Finland. Diagrams 3 and 4 correlate poorly with the models of social policy. The most homogeneous finding in this sense is probably the situation in the early 1980s when the primary distribution was clearly more unequal in the countries representing Central Europe than in other countries. This trend, however, disappears in the 1990s. 


\section{Trends of effectiveness of income transfer systems}

To complement the above comparisons, we compared the trends in poverty and income inequality before any income transfers with the situation after the income transfers. This analysis gives a more exact picture of the effectiveness of various income transfer systems. Table 2 presents to what extent the differences in poverty rate discussed above, and income inequality across the countries are explained by the effectiveness of the income transfer systems. Both absolute and relative figures are presented. "Reduction factor" indicates the extent to which the income transfers are capable of reducing the market-based poverty and income inequality. 
Table 2. The effectiveness of income transfers in reducing poverty and income equality in 19801995

\begin{tabular}{|c|c|c|c|c|}
\hline \multirow[b]{2}{*}{ Country and year } & \multicolumn{2}{|c|}{ Poverty rate } & \multicolumn{2}{|c|}{ Income inequality } \\
\hline & $\begin{array}{l}\text { Absolute effect, } \\
\% \text { points }\end{array}$ & $\begin{array}{c}\text { Reduction factor }^{2} \text {, } \\
\%\end{array}$ & $\begin{array}{l}\text { Absolute effect, } \\
\text { Gini index }\end{array}$ & $\begin{array}{c}\text { Reduction factor, } \\
\%\end{array}$ \\
\hline UK 1979 & 18 & 72 & 22 & 45 \\
\hline UK 1986 & 26 & 76 & 28 & 49 \\
\hline UK 1995 & 25 & 66 & 26 & 43 \\
\hline Canada 1981 & 10 & 45 & 13 & 30 \\
\hline Canada 1987 & 13 & 54 & 16 & 35 \\
\hline Canada 1991 & 16 & 62 & 19 & 40 \\
\hline Canada 1994 & 19 & 66 & 18 & 39 \\
\hline USA 1979 & 9 & 38 & 15 & 32 \\
\hline USA 1986 & 8 & 31 & 15 & 30 \\
\hline USA 1991 & 11 & 39 & 16 & 31 \\
\hline USA 1994 & 11 & 38 & 14 & 28 \\
\hline Netherlands 1983 & 23 & 85 & 29 & 52 \\
\hline Netherlands 1987 & 23 & 82 & 30 & 54 \\
\hline Netherlands 1991 & 24 & 83 & 27 & 49 \\
\hline Netherlands 1994 & 23 & 77 & 27 & 50 \\
\hline France 1979 & 23 & 74 & 21 & 40 \\
\hline France 1989 & 29 & 78 & 27 & 48 \\
\hline France 1994 & 31 & 79 & 26 & 46 \\
\hline Germany 1981 & 18 & 78 & 25 & 49 \\
\hline Germany 1984 & 19 & 76 & 26 & 50 \\
\hline Germany 1994 & 22 & 76 & 22 & 45 \\
\hline Norway 1979 & 17 & 81 & 16 & 41 \\
\hline Norway 1986 & 17 & 85 & 15 & 41 \\
\hline Norway 1991 & 20 & 87 & 18 & 45 \\
\hline Norway 1995 & 23 & 85 & 20 & 47 \\
\hline Sweden 1981 & 23 & 85 & 28 & 60 \\
\hline Sweden 1987 & 24 & 86 & 27 & 56 \\
\hline Sweden 1992 & 30 & 88 & 25 & 54 \\
\hline Sweden 1995 & 33 & 92 & 28 & 57 \\
\hline Finland 1981 & 15 & 68 & 16 & 42 \\
\hline Finland 1985 & 18 & 82 & 19 & 49 \\
\hline Finland 1990 & 22 & 88 & 20 & 50 \\
\hline Finland 1995 & 29 & 88 & 27 & 55 \\
\hline
\end{tabular}

Some readers may be surprised to observe that the absolute poverty-reducing effectiveness of social policy (measured in percentage points) actually increased in all countries during the study period; this in spite of the fact that many countries made significant cuts in their social policies during the same period. The Netherlands was exceptional in this respect: no change took place in one direction 
or the other. The primary reason for the rise of the absolute poverty-reducing effect is that in all these countries an essentially larger proportion of the population no longer received a sufficient livelihood through the primary market distribution. On the other hand, the income transfer systems vary significantly for the level of absolute effectiveness. In the USA, the income transfers allow only 10 percent of the population to pass the poverty line. In Canada - the second most modest country in this respect - the corresponding figure was two-fold in the mid-1990s. In France, Sweden and Finland, income transfers assist about 30 percent of the population over the poverty line.

The figures given in the second column complement the picture of the differences in the effectiveness of the systems; here the change in poverty before the income transfers is constant. The differences follow the theoretical models of social policy very well, with the means testing model showing the weakest effectiveness. The USA is an extreme: only slightly over one third of the people who are below the poverty line on the basis of market income are assisted over the poverty line by the social income transfers. Among the nine countries studied here, Canada and the UK follow the USA, although at a clear distance. In these countries, the poverty-reducing effect of income transfers is nearly twice that of the USA. Additionally, Canada and the UK have approached each other in this respect; the effectiveness deteriorated in the UK and improved in Canada during the period studied. In the Nordic countries, the current income transfers eradicate nearly 90 percent of the market-based poverty. The effectiveness has been increasing in the Nordic countries. Finland did not reach the "Nordic" level until in 1985; having had the third weakest poverty-reducing capacity among the nine countries in 1980. Central Europe is again positioned between the Englishspeaking countries and the Nordic countries. During the period studied, the countries representing the corporate model have come closer to each other, because the effectiveness of the Dutch system has fallen from the "Nordic" level in the early 1980s.

The countries differ from each other also in their effectiveness in reducing income inequality. Analysed by the income inequality, the picture of the differences in the effectiveness of the systems 
is not quite as clear. The income transfer systems of the USA and Canada are the most limited in this respect, too. Otherwise, the countries and models do not comply with the theoretical division of models (cf. Table 1). The countries representing different models, i.e. Sweden, Finland, the Netherlands, France and the UK, were equal in as far as the reduction of income inequality is concerned. The income transfer systems of these countries level out income differences more powerfully than the systems of the other countries in this study. The changes in the reducing effect did not indicate such a clear increase as was observed for poverty. In the USA, the Netherlands, Germany and Sweden the reducing impact remained unchanged or even decreased.

When the relative effect of reducing income inequality is compared across various income transfer systems (see Table 2, Column 4), Norway remains at the Central European level, while the Netherlands, Sweden and Finland are equal. The differences between the countries and the models of social policy are, in this respect, generally smaller than for the reduction of poverty. This result supports the idea of the "paradox of welfare" presented by Korpi and Palme (1998): Although focusing on the elimination of poverty, the means testing model is particularly inefficient in reducing poverty. In 1995, the income transfer systems of the USA, Canada and the UK were, relatively speaking, the least effective in reducing income inequality. The analysis shows that Finland did not reach the level of Sweden - the polestar of the Nordic model - until the (early) 1980s.

\section{Trends of poverty profiles}

Tables 3 and 4 illustrate the differences in poverty across the countries studied in relation to the life phases and market dependency. Of the various sectors of social policy, this analysis shows the effectiveness of pension policy, in particular. The results can be summarised in the following observations. It seems that poverty is no longer a problem pertaining specifically to the elderly in any Western country. As late as 1980 the poverty rate for the elderly was slightly above the average population-level rate in the USA, Germany, Norway and Finland. Fifteen years later poverty among 
the elderly was slightly below the average in all of the countries studied here. In fact, today the poverty rate for the elderly is "high" in the USA alone. In the Nordic countries, poverty among the elderly seems to have been overcome; the pension policy has been successful. Consequently, in the countries studied here, poverty is no longer an issue pertaining to the elderly.

Table 3. Poverty rates by population groups in 1980 and 1995, \% (1980/1995)

\begin{tabular}{|c|c|c|c|c|c|c|c|c|c|}
\hline & Canada & UK & USA & $\begin{array}{c}\text { Nether- } \\
\text { lands }\end{array}$ & France & Germany & Norway & Sweden & Finland \\
\hline $\begin{array}{l}\text { Total } \\
\text { population }\end{array}$ & $11 / 10$ & $7 / 12$ & $15 / 18$ & $4 / 7$ & $8 / 8$ & $5 / 7$ & $4 / 4$ & $4 / 4$ & $7 / 4$ \\
\hline \multicolumn{10}{|l|}{$\begin{array}{l}\text { Household } \\
\text { type }^{3}\end{array}$} \\
\hline 1 adult & $15 / 17$ & $6 / 6$ & $12 / 14$ & $2 / 10$ & $9 / 9$ & $5 / 8$ & $8 / 14$ & $7 / 9$ & $13 / 7$ \\
\hline 2 adults & $5 / 7$ & $3 / 5$ & $7 / 8$ & $1 / 3$ & $6 / 5$ & $3 / 4$ & $2 / 3$ & $3 / 1$ & $4 / 2$ \\
\hline $\begin{array}{l}2 \text { adults }+ \\
\text { child(ren) }\end{array}$ & $11 / 12$ & $9 / 17$ & $13 / 17$ & $2 / 7$ & $7 / 8$ & $2 / 8$ & $3 / 3$ & $5 / 2$ & $6 / 5$ \\
\hline $\begin{array}{l}\text { Single par- } \\
\text { ent }\end{array}$ & $42 / 37$ & $19 / 33$ & $50 / 50$ & $7 / 14$ & $17 / 18$ & $11 / 39$ & $9 / 9$ & $8 / 5$ & $10 / 5$ \\
\hline Elderly & $9 / 3$ & $5 / 6$ & $20 / 15$ & $4 / 5$ & $4 / 5$ & $8 / 4$ & $5 / 1$ & $0 / 1$ & $8 / 1$ \\
\hline Other & $8 / 7$ & $3 / 7$ & $12 / 17$ & 10 / 12 & $13 / 10$ & $6 / 5$ &..$/ 2$ &..$/$. & $6 / 4$ \\
\hline \multicolumn{10}{|l|}{$\begin{array}{l}\text { Number of } \\
\text { children }\end{array}$} \\
\hline 0 & $8 / 7$ & $4 / 6$ & $11 / 10$ & $4 / 6$ & $6 / 6$ & $5 / 5$ & $5 / 4$ & $3 / 4$ & $7 / 3$ \\
\hline 1 & $8 / 11$ & $4 / 11$ & $9 / 14$ & $5 / 10$ & $7 / 8$ & $3 / 7$ & $3 / 3$ & $3 / 3$ & $4 / 4$ \\
\hline 2 & $11 / 11$ & $6 / 15$ & $14 / 19$ & $3 / 8$ & $9 / 8$ & $3 / 10$ & $3 / 3$ & $5 / 3$ & $5 / 5$ \\
\hline 3 & $19 / 18$ & $11 / 23$ & $22 / 31$ & $3 / 6$ & $8 / 10$ & $8 / 16$ & $3 / 4$ & $7 / 3$ & $11 / 4$ \\
\hline $4+$ & $35 / 34$ & $26 / 54$ & $43 / 53$ & $8 / 17$ & $18 / 28$ & $13 / 24$ & $10 / 19$ & $16 / 6$ & $26 / 16$ \\
\hline \multicolumn{10}{|l|}{ Age } \\
\hline $18-30 \mathrm{yrs}$ & $14 / 18$ & $10 / 21$ & $17 / 31$ & $3 / 10$ & $6 / 14$ & $6 / 19$ & $8 / 16$ & $6 / 10$ & $9 / 11$ \\
\hline $30-64$ yrs & $11 / 10$ & $6 / 13$ & $14 / 16$ & $4 / 7$ & $9 / 8$ & $4 / 6$ & $3 / 3$ & $5 / 3$ & $6 / 3$ \\
\hline 65-yrs & $10 / 3$ & $5 / 6$ & $20 / 15$ & $4 / 5$ & $4 / 5$ & $8 / 4$ & $5 / 1$ & $0 / 1$ & $8 / 1$ \\
\hline \multirow{3}{*}{$\begin{array}{l}\text { Adult } \\
\text { members' } \\
\text { labour } \\
\text { particip. } \\
\text { All are } \\
\text { employed } \\
\text { Other } \\
\end{array}$} & & & & & & & & & \\
\hline & $6 / 5$ & $2 / 1$ & $9 / 9$ & $2 / .$. & $3 / 3$ & $1 / 3$ & $3 / 4$ & $3 / 3$ & $3 / 2$ \\
\hline & $18 / 18$ & $11 / 20$ & $23 / 29$ & $5 / .$. & $11 / 12$ & $6 / 11$ & $5 / 6$ & $8 / 5$ & $5 / 7$ \\
\hline
\end{tabular}

For various types of households, it is worth mentioning that the countries and the models of social policy differ from each other as far as the poverty risk among single parents is concerned. In the 
USA, every second single parent lives in poverty; in Canada and the UK every third. For the Central European countries, a substantial rise in the risk of poverty for single parents is observable during the study period of 15 years. The increase has been particularly rapid in Germany. In this respect, the Nordic countries stand alone. The risk of poverty among single parents was about 10 percent in the 1980s, and it fell to one half by the mid-1990, and did not significantly differ from the average risk at population level. Thus, single parenthood is today a significant issue in the overall picture of poverty mainly in Canada, the UK, the USA and Germany. In these countries, one fifth of the total poverty is estimated to be caused by the insufficient income level of single parent families (Table 4).

Not only single parent families, but also other families with children are at a high risk of poverty, in particular in the countries where means testing plays a key role in social policy. In Canada and the USA, 70-75\% of the poor people live in families with children, in the UK the share is as high as 80\%. In the Central European countries, especially in Germany, the proportional share of the poor people living in families with children is rising dramatically. The Netherlands and France show a similar trend, though at a slower pace. The Nordic countries differ from the other countries: Poverty predominantly affects single people and childless couples. In Norway and Sweden, the majority of the poor live in a childless household. The proportional share of single people among the poor has been increasing in all of the countries studied. It is difficult to analyse the associations between single living and poverty, because so many young people and elderly people live alone. The variation in these groups' livelihood is not discussed in detail here. Based on the poverty rates among the elderly people, however, it can be assumed that the risk of poverty among single people is increased by the high poverty risk among young single people; this again is associated with the high rate of youth unemployment and the low income level during periods of study. The rise of poverty among young households is a trend shared by all of the countries studied. Additionally, the poverty rate for households in the age group 18-30 years was above the average poverty at 
population level in all the countries both in 1980 and 1985, with the exception of the Netherlands and France in 1980. This indicates that youth, rather than old age, is affected by poverty in the Western world today.

Table 4. Poverty profiles in 1980 and 1995, \% (1980/1995)

\begin{tabular}{|c|c|c|c|c|c|c|c|c|c|}
\hline & Canada & UK & USA & $\begin{array}{c}\text { Nether- } \\
\text { lands }\end{array}$ & France & Germany & Norway & Sweden & Finland \\
\hline \multicolumn{10}{|l|}{$\begin{array}{l}\text { Household } \\
\text { type }\end{array}$} \\
\hline 1 adult & $10 / 10$ & $3 / 3$ & $4 / 5$ & $2 / 12$ & $4 / 8$ & $7 / 9$ & $14 / 38$ & $18 / 19$ & $18 / 20$ \\
\hline 2 adults & $6 / 12$ & $6 / 7$ & $6 / 7$ & $3 / 9$ & $9 / 9$ & $9 / 8$ & $5 / 8$ & 17 / 17 & $9 / 9$ \\
\hline $\begin{array}{l}2 \text { adults }+ \\
\text { child(ren) }\end{array}$ & $41 / 41$ & $60 / 54$ & $34 / 36$ & 17 / 38 & $36 / 39$ & $18 / 40$ & $40 / 28$ & $41 / 37$ & $34 / 43$ \\
\hline $\begin{array}{r}\text { Single par- } \\
\text { ent }\end{array}$ & $19 / 19$ & $10 / 20$ & $21 / 20$ & $5 / 6$ & $4 / 8$ & $5 / 19$ & $22 / 13$ & $6 / 8$ & $5 / 5$ \\
\hline Elderly & $10 / 4$ & $13 / 8$ & $17 / 12$ & $12 / 9$ & $8 / 11$ & $32 / 11$ & $18 / 5$ & $19 / 19$ & $14 / 4$ \\
\hline Other & $15 / 15$ & $8 / 8$ & $17 / 20$ & $60 / 26$ & $38 / 26$ & $29 / 13$ & $1 / 9$ & .. / .. & $21 / 19$ \\
\hline Total & 100 & 100 & 100 & 100 & 100 & 100 & 100 & 100 & 100 \\
\hline \multicolumn{10}{|l|}{$\begin{array}{l}\text { Number of } \\
\text { children }\end{array}$} \\
\hline 0 & $26 / 31$ & $23 / 20$ & $27 / 25$ & 45 / 41 & $31 / 36$ & $52 / 34$ & 32 / 52 & $53 / 55$ & $46 / 38$ \\
\hline 1 & $14 / 18$ & $11 / 14$ & $12 / 15$ & $22 / 19$ & $16 / 19$ & $14 / 20$ & $14 / 13$ & $17 / 14$ & $12 / 18$ \\
\hline 2 & $24 / 24$ & $24 / 28$ & $20 / 23$ & $21 / 25$ & $25 / 20$ & $15 / 25$ & $18 / 15$ & $21 / 20$ & $18 / 25$ \\
\hline 3 & $20 / 16$ & $19 / 18$ & $17 / 19$ & $7 / 8$ & $11 / 11$ & $14 / 14$ & 13 / 10 & $8 / 8$ & $13 / 7$ \\
\hline $4+$ & $16 / 12$ & $24 / 20$ & $25 / 18$ & $5 / 7$ & $17 / 14$ & $6 / 8$ & $23 / 10$ & $2 / 3$ & $12 / 12$ \\
\hline Total & 100 & 100 & 100 & 100 & 100 & 100 & 100 & 100 & 100 \\
\hline \multicolumn{10}{|l|}{ Age } \\
\hline$<30 \mathrm{yrs}$ & $21 / 20$ & $22 / 20$ & $20 / 24$ & $10 / 15$ & $8 / 17$ & $12 / 25$ & $29 / 50$ & 17 / 16 & $20 / 34$ \\
\hline $30-64$ yrs & $69 / 76$ & $65 / 72$ & $63 / 64$ & $78 / 76$ & $84 / 72$ & $56 / 64$ & 53 / 46 & 65 / 66 & $66 / 63$ \\
\hline 65-yrs & $10 / 4$ & $13 / 8$ & $17 / 12$ & $12 / 9$ & $8 / 11$ & $32 / 11$ & $18 / 5$ & $19 / 19$ & $14 / 4$ \\
\hline Total & 100 & 100 & 100 & 100 & 100 & 100 & 100 & 100 & 100 \\
\hline \multirow{2}{*}{\multicolumn{10}{|c|}{\begin{tabular}{|l|l|}
$\begin{array}{l}\text { Adult } \\
\text { members' }\end{array}$ & \\
labour & \\
particip. & \\
All are & \\
employed & $32 / 30$
\end{tabular}}} \\
\hline & & & & & & $8 / 18$ & $50 / 58$ & $67 / 73$ & $26 / 32$ \\
\hline $\begin{array}{l}\text { Other } \\
\text { Total }\end{array}$ & $\begin{array}{c}68 / 70 \\
100\end{array}$ & $\begin{array}{c}85 / 96 \\
100\end{array}$ & $\begin{array}{c}67 / 69 \\
100\end{array}$ & $\begin{array}{c}93 / 100 \\
100\end{array}$ & $\begin{array}{c}87 / 84 \\
100\end{array}$ & $\begin{array}{c}92 / 82 \\
100\end{array}$ & $\begin{array}{c}50 / 42 \\
100\end{array}$ & $\begin{array}{c}33 / 27 \\
100\end{array}$ & $\begin{array}{c}74 / 68 \\
100\end{array}$ \\
\hline
\end{tabular}

In all of the countries studied, poverty is predominantly a problem of those households in which not all adult members are gainfully employed. Gainful work as such does not necessarily provide 
sufficient subsistence; however, the results of the present analysis do not indicate that the "working but poor" phenomenon is increasing.

\section{Conclusions}

The most important results of our cross-national comparison of trends in poverty and income equality between the years 1980 and 1995 are as follows: The differences in poverty across the countries studied corresponded with the respective models of social policy more clearly in the late 1990s than they did 15 years earlier. There are numerous explanations for this finding. First, in the UK the poverty rate has risen to the high level that is typical of a society exercising social policy based on means testing. At the same time, poverty rate in Finland has fallen to the low level characteristic of the Nordic countries. The Central European countries have approached each other in this respect, as the Dutch and German poverty rates rose to the French level, being clearly higher than that in the Nordic countries and lower than in the English-speaking countries. The poverty rates in the Englishspeaking countries - with a social policy based on means testing - differ greatly from each other. The USA is in a class of its own, at a clear distance ahead of the UK and Canada. Throughout the study period, the US poverty rate has been at least 5 percentage points higher than that of the country with the second highest level of poverty.

Generally speaking, the poverty rate is slightly under 5\% in the Nordic countries, around $7.5 \%$ in Central Europe, $10 \%$ in Canada, $12.5 \%$ in the UK, and as high as $17.5 \%$ in the USA.

All the countries included in the analysis share the trend that the primary distribution - based on the market income - has become less equal than before. In each country, the proportion of population being able to gain subsistence from the market alone has decreased continuously. This trend is significantly more remarkable than the change in actual poverty. If the effectiveness of the social policy in equalising and redistributing incomes had not improved in general, poverty would have increased more than it did in the countries studied (except the Netherlands). The fact that the market 
income distribution guarantees subsistence for a smaller proportion of population than before is explained by, among other things, the increase of unemployment and ageing of the population. The countries differ from each other in their capability to fill, by means of income transfers, the widening gaps resulting from the market-oriented distribution. In the UK, in particular, the relative poverty-reducing effectiveness of the system has deteriorated; with the cuts in the income security system as an underlying mechanism. It must, however, be pointed out that the variation in poverty across the countries and the models of social policy is much smaller before than after the income transfers. This indicates that the association between the social policy model and the poverty rate observed in 1995 results specifically from the differences in the effectiveness in the income transfer systems. The least efficient in eradicating poverty are the systems based on means testing, in which the redistribution arrangements are directed only to the poorest in society. The finding is in line with previous results (cf. Korpi \& Palme 1998).

The analysis of income inequality produced a basically similar picture of the differences across the countries and the models of social policy as the analysis of poverty did. In comparison to poverty, however, the change is generally speaking less extensive. The Nordic countries, in particular, have been capable of responding to the rise of the market income differences so that the income inequality for disposable incomes has practically not increased at all. Canada shows a parallel trend. The USA and, in particular, the UK represent the opposite development. The currently prevailing income differences in the UK are more or less equal to the "very high" income inequality of the USA. Reasons for this development include cuts in the systems intended to level out income inequality and the increasing unemployment.

For this study, we also analysed the differences in poverty in relation to various population groups. It was found that nowadays in all the countries studied the poverty rate among the elderly people is below the average population-level rate. In the wealthy Western countries, poverty is no longer an issue pertaining specifically to the elderly. Rather the opposite: the risk of poverty is 
highest among young adults. One reason for this is that, as a phase of life, young adulthood is typically a time for studying, or is shadowed by youth unemployment, instead of being a time of active working. Both factors are associated with a high risk of livelihood problems. Families with children are affected by poverty especially in countries where means testing is a key principle in social policy. In Central Europe too, the risk of poverty for families with children and their role in the overall picture of poverty has increased dramatically. The Nordic countries show a different pattern of poverty in this respect. The overall poverty risk is low, and if the population groups are analysed separately, it is found that people living alone are at a higher risk of poverty in the Nordic countries. Also, the economic position of single parent households varies in different countries; generally speaking, the status of single parents is significantly better in the Nordic countries than elsewhere.

"Working but poor" is a phenomenon that has been debated in international forums recently. To investigate this issue in rather broad terms, we examined the households in which all adult members are gainfully employed and the other households, and found that the risk of poverty differs greatly in all countries for these two groups. It can still be argued that earned income is the primary protection against poverty. In this analysis we did not compare families with one provider and families with two providers. The results of previous research are clear; the two-provider model safeguards subsistence significantly better (cf. Kangas \& Ritakallio 2000). In the "working but poor" debate, the situation in the USA deserves special consideration. The incomes of a tenth of the "fully employed" households in the USA fall below the poverty line. The situation was similar in 1980, so the effects of the economic and social policy known as the "Reaganism" are not reflected so much in this respect as in the general increase of poverty and income inequality. Encouraging people to work has been the main incentive used in the US social policy. Apparently, there are problems in this policy, as a tenth of the people employed in the world's richest country live in continuous poverty. 
Our research shows that the effectiveness of income transfer systems varies significantly across the countries and the models of social policy. Principally the differences are rather constant. The income inequality, poverty and effectiveness of the redistribution system of the USA are at one end, while Sweden and Norway are at the other end of the scale. In these countries, the situation is stable. Comparison over the study period of 15 years showed, however, that the situation in each particular country can differ from time to time. Major changes have taken place, in particular in the UK and Finland, but also in Canada, the Netherlands and Germany. In one country, the change is for the better, in another for the worse. The changes do not correlate clearly with the changes occurring in the labour market or in the population profile; on the contrary, it seems that they primarily reflect alterations in social policy. Hypothetically, if the effectiveness of the Swedish system were identical to that of the system in the USA in 1995 (92\% vs. 38\%), the poverty rate in Sweden would have been 22.3 percent instead of 3.5 percent. The way of implementing social policy does matter! 


\section{Appendices}

Appendix 1. Structural differences between the countries by family type, number of children, age, and labour participation in 1980 and 1995, \% (1980/1995)

\begin{tabular}{|c|c|c|c|c|c|c|c|c|c|}
\hline & Canada & UK & USA & $\begin{array}{l}\text { Nether- } \\
\text { lands }\end{array}$ & France & Germany & Norway & Sweden & Finland \\
\hline \multicolumn{10}{|l|}{$\begin{array}{l}\text { Household } \\
\text { type }\end{array}$} \\
\hline 1 adult & $8 / 6$ & $4 / 6$ & $5 / 6$ & $4 / 8$ & $4 / 7$ & $6 / 8$ & $7 / 11$ & $18 / 19$ & $9 / 11$ \\
\hline 2 adults & 13 / 17 & 14 / 17 & $14 / 15$ & 15 / 21 & $12 / 14$ & $14 / 16$ & $9 / 13$ & 17 / 17 & $14 / 19$ \\
\hline $\begin{array}{l}2 \text { adults }+ \\
\text { child(ren) }\end{array}$ & $41 / 36$ & 45 / 39 & $39 / 36$ & 43 / 39 & $43 / 39$ & $38 / 35$ & $57 / 35$ & $41 / 37$ & $39 / 32$ \\
\hline $\begin{array}{r}\text { Single par- } \\
\text { ent }\end{array}$ & $5 / 5$ & $4 / 8$ & $6 / 7$ & $3 / 3$ & $2 / 3$ & $2 / 4$ & $11 / 6$ & $6 / 8$ & $3 / 5$ \\
\hline Elderly & $11 / 13$ & $16 / 17$ & $13 / 14$ & $13 / 14$ & $16 / 17$ & $18 / 18$ & $16 / 18$ & 19 / 19 & $11 / 15$ \\
\hline Other & $23 / 23$ & $18 / 14$ & $23 / 21$ & $22 / 16$ & $23 / 20$ & $21 / 19$ & $-/ 17$ & - & $24 / 19$ \\
\hline \multicolumn{10}{|c|}{$\begin{array}{l}\text { Number of } \\
\text { children }\end{array}$} \\
\hline 0 & $39 / 48$ & 39 / 47 & $39 / 42$ & $42 / 51$ & $40 / 48$ & $46 / 53$ & 30 / 51 & $53 / 55$ & $45 / 55$ \\
\hline 1 & $20 / 17$ & $18 / 16$ & $20 / 19$ & $19 / 14$ & $20 / 19$ & $22 / 20$ & $18 / 18$ & $17 / 14$ & $22 / 16$ \\
\hline 2 & $25 / 22$ & $26 / 23$ & $22 / 22$ & $28 / 23$ & $22 / 20$ & $21 / 19$ & $26 / 20$ & $21 / 20$ & $23 / 19$ \\
\hline 3 & $12 / 9$ & $11 / 10$ & $11 / 11$ & $9 / 9$ & $11 / 9$ & $8 / 6$ & 17 / 10 & $8 / 8$ & $7 / 8$ \\
\hline $4+$ & $5 / 4$ & $6 / 5$ & $9 / 6$ & $3 / 3$ & $8 / 4$ & $2 / 2$ & $9 / 2$ & $2 / 3$ & $3 / 3$ \\
\hline \multicolumn{10}{|l|}{$\overline{\text { Age }}$} \\
\hline$<30 \mathrm{yrs}$ & $17 / 11$ & $15 / 12$ & $18 / 13$ & $12 / 11$ & $11 / 9$ & $10 / 10$ & $15 / 13$ & $17 / 16$ & $15 / 12$ \\
\hline $30-64 \mathrm{yrs}$ & $72 / 76$ & 69 / 71 & $69 / 72$ & $75 / 75$ & $73 / 73$ & $72 / 72$ & 69 / 69 & 65 / 66 & $74 / 73$ \\
\hline $65-\mathrm{yrs}$ & $11 / 13$ & $16 / 17$ & $13 / 14$ & $13 / 14$ & $16 / 17$ & $18 / 18$ & $16 / 18$ & $19 / 19$ & $11 / 15$ \\
\hline \multicolumn{10}{|c|}{$\begin{array}{l}\text { Adult } \\
\text { members' } \\
\text { labour } \\
\text { particip. } \\
\quad \text { All are }\end{array}$} \\
\hline $\begin{array}{r}\text { employed } \\
\text { Other }\end{array}$ & $\begin{array}{l}5 / 78 \\
44 / 42\end{array}$ & $\begin{array}{l}49 / 40 \\
51 / 60\end{array}$ & $\begin{array}{l}55 / 58 \\
45 / 42\end{array}$ & $\begin{array}{l}20 / . . \\
80 / . .\end{array}$ & $\begin{array}{l}33 / 43 \\
67 / 57\end{array}$ & $\begin{array}{l}35 / 44 \\
65 / 56\end{array}$ & $\begin{array}{l}61 / 70 \\
39 / 30\end{array}$ & $\begin{array}{l}67 / 73 \\
33 / 27\end{array}$ & $\begin{array}{l}50 / 59 \\
50 / 41\end{array}$ \\
\hline
\end{tabular}


Appendix 2. Data-sets used in the analyses

\begin{tabular}{|c|c|c|}
\hline \multicolumn{3}{|c|}{ Country and year Name and size of the dataset (number of households) ${ }^{4}$} \\
\hline \multirow[t]{4}{*}{ Canada } & 1981 & Survey of Consumer Finances, 15045 \\
\hline & 1987 & Survey of Consumer Finances, 10975 \\
\hline & 1991 & Survey of Consumer Finances, 20827 \\
\hline & 1994 & Survey of Consumer Finances, 37388 \\
\hline \multirow[t]{3}{*}{ UK } & 1979 & The Family Expenditure Survey, 6758 \\
\hline & 1986 & The Family Expenditure Survey, 7091 \\
\hline & 1995 & The Family Expenditure Survey, 6750 \\
\hline \multirow[t]{4}{*}{ USA } & 1979 & March Current Population Survey, 14257 \\
\hline & 1986 & March Current Population Survey, 11545 \\
\hline & 1991 & March Current Population Survey, 14629 \\
\hline & 1994 & March Current Population Survey, 56528 \\
\hline \multicolumn{2}{|c|}{ Netherlands 1983} & Additional Enquiry on the Use of (Public) Services, 4670 \\
\hline & 1987 & Additional Enquiry on the Use of (Public) Services, 4097 \\
\hline & 1991 & Socio-Economic Panel (SEP), 4326 \\
\hline & 1994 & Socio-Economic Panel (SEP), 5134 \\
\hline \multirow[t]{3}{*}{ France } & 1979 & The French Survey of Income from Income Tax, 10989 \\
\hline & 1989 & Family Budget Survey, 8515 \\
\hline & 1994 & Family Budget Survey, 11286 \\
\hline \multirow[t]{3}{*}{ Germany } & 1981 & Transfer Survey, 2727 \\
\hline & 1984 & Social Economic Panel Study, 5159 \\
\hline & 1994 & Social Economic Panel Study, 5829 \\
\hline \multirow[t]{4}{*}{ Norway } & 1979 & Income and Property Distribution Survey, 10307 \\
\hline & 1986 & Income and Property Distribution Survey, 4967 \\
\hline & 1991 & Income and Property Distribution Survey, 8059 \\
\hline & 1995 & Income and Property Distribution Survey, 10101 \\
\hline \multirow[t]{4}{*}{ Sweden } & 1981 & Income Distribution Survey, 9523 \\
\hline & 1987 & Income Distribution Survey, 9298 \\
\hline & 1992 & Income Distribution Survey, 12252 \\
\hline & 1995 & Income Distribution Survey, 15823 \\
\hline \multirow[t]{4}{*}{ Finland } & 1981 & Household Expenditure Survey, 7368 \\
\hline & 1985 & Household Expenditure Survey, 8200 \\
\hline & 1990 & Household Expenditure Survey, 8258 \\
\hline & 1995 & Household Expenditure Survey , 9249 \\
\hline
\end{tabular}




\section{Litterature}

Atkinson, A., Rainwater, L. and Smeeding, T. (1995). Income Distribution in OECD Countries. Evidence from the Luxembourg Income Study. OECD: Paris.

Bradbury, B. \& Jäntti, M. (1999). Child Poverty Across Industrialized Nations. UNICEF, Economic and Social policy Series 71. Florence.

Bradshaw, J. (1999). The nature of poverty. In Ditch, J. (ed.) Introduction to Social Security. Policies, benefits and poverty. Routledge, London.

Buhmann, B., Rainwater, L., Scmaus, G. \& Smeeding., T. (1988) "Equivalence Scales, Well-Being, Inequality and Poverty." Review of Income and Wealth 34 (2) (June), 115-142.

Castles F. (1985). Working Class and Welfare: Reflections on the Political Development of the Welfare State in Australia and New Zealand, 1890-1980. Allen \& Unwin, Sydney.

Castles, F. \& Mitchell, D. (1990). Three Worlds of Welfare Capitalism or Four? The Australian National University, Public Policy Program, Discussion Paper No. 21.

Esping-Andersen, G. (1990). The Three Worlds of Welfare Capitalism. Oxford, Polity Press.

Forssén, K. (1998). Children, Families and the Welfare State. Studies on the Outcomes of the Finnish Family Policy. National Research and Development Centre for Welfare and Health: Helsinki. 
Gottschalk, P., Gustafsson, B. \& Palmer E. (1997) "What's behind the increase in inequality? In Gottschalk, P., Gustafsson, B. \& Palmer, E (eds.) Changing Patterns in the distribution of economic welfare. Cambridge University Press, Cambridge. Pp. 1-11.

Gustafsson, B. \& Uusitalo, H. (1990). Income Distribution and Redistribution during Two Decades: Experiences from Finland and Sweden. In Persson, I. (ed.). Generating Equality in the Welfare State. The Swedish Experience. Norwegian University Press, Stavanger. 73-95.

Kangas, O. \& Palme, J. (1998). Does social policy matter? Poverty cycles in OECD countries. Luxembourg Income Study -working papers 188.

Kangas, O. \& Ritakallio, V-M. (2000). "Social Policy or Structure? Income Transfers, Sociodemographic Factors and Poverty in the Nordic Countries and in France”. In: Palier, B. \& Boguet, D. (eds.). Comparing Social Welfare Systems in Nordic Europe and France - Vol. 4. MIRE, Paris, 513-540.

Korpi, W. (1983). The Democratic Class Struggle. Routledge \& Kegan Paul, London.

Korpi, W. \& Palme, J. (1993). Socialpolitik, kris och reformer: Sverige i internationell belysning. [Social policy, crisis and reforms: Sweden in international comparison]. In: Nya villkor för ekonomi och politik. Ekonomikomissionens förslag, bilagdel 2. Statens offentliga utredningar 1993:16, Finansdepartementet, 135-170. Stockholm.

Korpi, W. \& Palme, J. (1998). “The Paradox of Redistribution and Strategies of Equality: Welfare State Institutions, Inequality and Poverty in the Western Countries. American Sociologigal Review 63, 661-687. 
Leibfried, S. \& Ostner, I. (1991). The Particularism of West German Welfare Capitalism: The Case of Women's Social Security. In Adler, M., Bell, C., Clasen, J. \& Sinfield, A. (eds.). The Sociology of Social Security. Edinburgh University Press. 164-186.

Mitchell, D. (1991). Income Transfers in Ten Welfare States. Avebury: Aldershot.

Rainwater, L. and Smeeding, T (1998). "Demography or Income Packaging?: What Explains the Income Distribution of The Netherlands?” In Galler, H. and Wagner, G. (eds). Empirische Forschung und wirtschaftspolitische Beratung [Empirical Research and Economic Policy Discussion]: Commemorative Volume for Hans-Jürgen Krupp, Economic Research, Volume 38, 1998:99-118.

Ringen, S. (1987). The Possibility of Politics. A Study in the Political Economy of the Welfare State. Clarendon Press: Oxford.

Rowntree, S. (1901). Poverty. The Study of Town Life. Macmillan: London.

Sainsbury, D. (ed.) (1994). Gendering Welfare States. Sage: London.

Saunders, P. (1994). Welfare and Inequality: National and International Perspectives on the Australian Welfare State. Cambridge University Press: Cambridge.

Sawyer, M. (1976) Income Distribution in OECD Countries. OECD Economic Outlook - Occasional Studies. Paris, OECD. 
Schneider, J. (1999). The Increasing Financial Dependency of Young People on Their Parents. SPRC Discussion Paper No. 96. University of New South Wales, Sydney.

Smeeding, T., P. Saunders, J. Coder, S. Jenkins, J. Frizell, A. Hagenars, R. Hauser \& Wolfson, M. (1993) Poverty, Inequality, and Family Living Standards. Impacts Across Seven Nations: The Effect of Noncash Subsidies for Health, Education and Housing. Review of Income and Wealth 39 (3), 229-255.

Titmuss, R. 1958. Essays on the Welfare State. Allen \& Unwin, London.

Uusitalo, H. (1989). Income Distribution in Finland. The Effects of the Welfare State and the Structural Changes in Society on Income Distribution in Finland in 1966-1985. Central Statistical Office Finland, Studies no. 148. Helsinki.

\section{Endnotes}

\footnotetext{
${ }^{1}$ For UK, the data are from year 1990, and for France and Germany, the data for 1985 are lacking, because no material is available. In the Swedish material, children aged over 18 years living at home are recorded as independent households. Consequently, the LIS analyses usually produce an overestimated value for the poverty among people living alone in Sweden. In the present analysis, this is corrected by excluding the single living individuals aged under 30 years and having incomes at least $40 \%$ below the poverty line.

${ }^{2}$ The value before income transfers minus the value after income transfers, divided by the value before income transfers altogether multiplied by 100 .

${ }^{3}$ The family type variable is constructed by means of OECD equivalence figures.

${ }^{4}$ Institutionalized and homeless people are not represented in any set of data.
} 